\title{
Structure of the Carboniferous Altenberg-Teplice Caldera (Eastern part of the Krušné hory/Erzgebirge Mts.) revealed by combined airborne and ground gamma-ray spectrometry
}

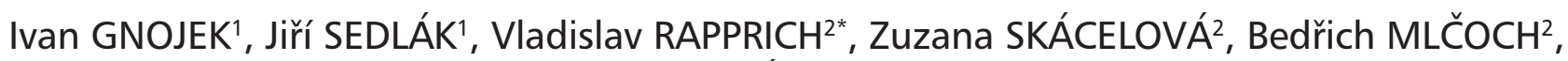 Ottomar KRENTZ ${ }^{3}$, Raymundo CASAS-GARCÍA ${ }^{4}$}

\author{
${ }^{1}$ Miligal, Ltd. Axmanova 531/13, 62300 Brno, Czech Republic; miligal@miligal.cz \\ ${ }^{2}$ Czech Geological Survey, Klárov 3, 11821 Prague 1, Czech Republic; vladislav.rapprich@geology.cz \\ ${ }^{3}$ Landesamt für Umwelt, Landwirtschaft und Geologie, Postfach 5401 37, 01311 Dresden, Germany \\ ${ }^{4}$ Institute of Geology and Palaeontology, TU Bergakademie Freiberg, Bernhard-von-Cotta-Str. 2, 09599 Freiberg, Germany \\ * Corresponding author
}

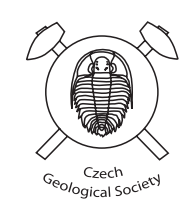

The airborne gamma-ray spectrometry images from the Czech and German parts of the Carboniferous Altenberg-Teplice Volcanic Complex (ATVC) - both obtained during independent surveying campaigns - were merged to display the structure of the caldera fill (dominated by rhyolitic ignimbrites) and associated intrusive bodies. The airborne systematic measurements were supported by the ground- and laboratory gamma-ray spectrometry analyses (K, U, Th) of representative lithologies from outcrops and drill-cores.

Significant differences were identified between the younger and older (post- and pre-caldera respectively) intrusive complexes related to the ATVC. The younger Schellerhau granite displays 1.5-3.0 $\times$ higher concentrations of radioactive elements than the older Fláje granite.

The ATVC was found to be split by the NW-SE trending Altenberg Fault into a southern and a northern segment that expose different stratigraphic levels of the caldera's fill. The individual types of rhyolite ignimbrites defined in the Czech part of the ATVC are characterized by distinct concentrations of natural radioactive elements which enable identification of the individual types from the airborne gamma-spectrometry image. These characteristics were compared to data obtained from the German part, and several lithological types were unified to common units.

A single Th-rich unit (Pramenáč type in Czech part, Lugstein type in Germany and Teplice Rhyolite TR3a in Mi-4 borehole) can be traced across the entire caldera and may serve as the principal correlation member. Inclusion of the Vrchoslav type into this TR3a unit remains speculative due to lack of data, and further petrological research is required. On the other hand, Vlčí kámen and Medvědí vrch types from opposite sides of the caldera display identical properties allowing to merge them into a common unit TR3b overlain by the youngest unit TR4 (Přední Cínovec type) - restricted to the Czech territory. This result may suggest partly synclinal structure within the southern ATVC segment. The TR4 unit has a strong compositional tendency towards the post-ignimbrite granite porphyry intrusions.

Some lithotypes in the northern segment (e.g., Buschmühle) do not have counterparts on the Czech side and most likely represent an independent volcanic unit in the northern, presumably older, part of the caldera.

The uniform composition of the rhyolitic rocks observed in the entire profiles of the drillings located in the Town Teplice (TP-39 reaching $1170 \mathrm{~m}$ depth) may suggest that the main feeding conduit system for the TR4 ignimbrite was located within the Teplice-Lahošt' horst area.

Keywords: Saxothuringian zone, Altenberg-Teplice Caldera, airborne gamma-ray spectrometry, ground gamma-ray spectrometry, petrophysics, rhyolite

Received: 20 October 2017; accepted: 6 March 2018; handling editor: A. Guy

The online version of this article (doi: 10.3190/jgeosci.251) contains supplementary electronic material.

\section{Introduction}

Geophysical methods bring valuable data on geological structures, namely in areas with poor access and/or exposures. Many of the geophysical methods are available also in airborne mode allowing rapid and systematic cover of larger areas by coherent continuous datasets. In the complexes comprising abundant naturally radioactive rocks, gamma-ray spectrometry plays a crucial role
(Chiozzi et al. 2001, 2003; Gehring 2004; Skácelová et al. 2009; Sedlák et al. 2011; Attia and Wahid 2016; Paoletti et al. 2016; Weihermann et al. 2016). In such areas, the airborne gamma-ray spectrometry helps in mapping inaccessible or macroscopically indistinguishable units. Slight differences in composition of rocks are reflected by distinct concentrations of natural radioactive elements $(\mathrm{K}, \mathrm{U}$, and $\mathrm{Th}$ ) resulting in variable gamma-ray patterns. Variability of $\mathrm{K}, \mathrm{U}$ and $\mathrm{Th}$ concentrations and 
their concentration ratios enable to distinguish individual lithologies and can be a useful tool in structural studies of igneous complexes. In addition, actual demands on clean-energy resources result in employing the gammaray spectrometry in geothermal exploration (e.g., McCay et al. 2014; McCay and Younger 2017).

Complex evolution with several ignimbrite, lava and intrusive units differing in composition is characteristic of the Altenberg-Teplice Volcanic Complex (ATVC) in the eastern part of Krušné hory/Erzgebirge Mts. (e.g., Breiter et al. 2001; Müller et al. 2005). The new airborne maps embracing its area (covering c. $900 \mathrm{~km}^{2}$ ) limited by the points of Litvínov (SW) - Frauenstein (NW) - Ulbendorf (NE) - Teplice (SE) are presented and the geophysical responses of the volcanic complex are discussed. The aim of the article is to demonstrate the abilities of the combined airborne, ground and laboratory gamma-ray spectrometry $(\mathrm{K}, \mathrm{U}, \mathrm{Th})$ in defining and mapping lithological varieties of the individual geological bodies (e.g. ignimbrite units), using the ATVC as a case study.

\section{Geological setting}

The Altenberg-Teplice Volcanic Complex (ATVC) is an accumulation of Early to Late Carboniferous volcanic and intrusive rocks. Its erosional remnants occupy the eastern part of the Altenberg-Teplice Caldera (ATC) situated in the eastern Krušné hory/Erzgebirge Mts. (Fig. 1a), but ATVC includes also erosional relics of caldera outflow facies in the south.

The magmatic activity in the area of ATC started with Older Intrusive Complex represented by Fláje biotite S-type granite (Fig. 1b; undated but from geological relations considered as predating formation of the ATVC: Štemprok et al. 2003; Romer et al. 2010). Walther et al. (2016) presumed that the Fláje granite might represent intrusive equivalent of the ATVC older member, known as Schönfeld-Altenberg Depression Complex (SADC; Westphalian B/C: Lobin 1986; U-Pb zircon age $326.8 \pm 4.3$ Ma: Hoffmann et al. 2013), but clear evidence for a link between this intrusion and SADC volcanic rocks is still missing. The SADC rocks crop out in the northern (German) part of the ATVC, but were only documented on the Czech side in the Mi-4 drilling (Fig. 1c). The SADC comprise dacitic lavas and associated mass-flow deposits, dacitic to rhyolitic ignimbrites and fall-out tuffs and sedimentary layers (Walther et al. 2016).

The SADC is buried by a thick rhyolitic caldera-fill succession $(\leq 1000 \mathrm{~m}$, Mlčoch and Skácelová 2010), dominated by crystal-clast- and pumice-rich welded ignimbrites with subordinate lavas (Lobin 1986; Jiránek et al. 1987), known as the Teplice Rhyolite (TR), accompanied by granite and granite porphyry (microgranite) intrusions. The TR also contains subordinate lava complexes and two intercalations of volcaniclastic sediments, suggesting step-wise caldera evolution. The ATC represents a $18 \times 35 \mathrm{~km}$ large collapse caldera of trapdoor type with deeper subsidence in the east (Benek 1991; Mlčoch and Skácelová 2010).

The eastern and deeper-sunk part of the caldera is filled up with thick accumulations of the Teplice Rhyolite ignimbrites (Fig. 1b; Moesta 1929; Müller et al. 2005). The outcropping part of the Teplice Rhyolite was subdivided on the Czech side into seven petrographic types (Eisenreich and Jeřábek 1978; Jiránek et al. 1987; Fig. 1c) - from west to east: Western margin, Pramenáč, Vlčí kámen, Přední Cínovec, Medvědí vrch, Vrchoslav (all ignimbrites) and Lysá hora (a lava unit). Similarly, eight petrographic types were defined on the German side of the ATVC: Barmenberg, Schmiedeberg, Molchgrund, Buschmühle, Langer Grundbach, Teichweg, Lugstein and Altenberg (Lobin 1986; Fig. 1c). These types represent individual stages of the ATVC evolution, but their correlation across the border remains partly unclear. Distinct lithological types of Teplice Rhyolite can be distinguished in several drill cores, such as the Mi-4 borehole (Eisenreich 1985; Breiter et al. 2001).

During the late stage of the ATVC evolution, coarsely porphyritic microgranites were emplaced (the AltenbergFrauenstein microgranite; Müller and Seltmann 2002; Müller et al. 2005; Breiter et al. 2012, 2013). These thick porphyry dykes form an almost continuous ring around the ATC (Fig. 1a; Müller and Seltmann 2002; Mlčoch and Skácelová 2010). Romer et al. (2010) reported an age of $319.2 \pm 2.4 \mathrm{Ma}(\mathrm{U}-\mathrm{Pb}$ zircon) for a microgranitic dyke crosscutting the Teplice ignimbrite. Later, monzo- and syenogranites were also emplaced (Schellerhau granite: Pälchen and Ossenkopf 1967) and Sn-Li granites (Altenberg, Cínovec) of the Younger Intrusive Complex (A-type granitoids) (Förster et al. 1999; Johan et al. 2012; Štemprok and Blecha 2015; Štemprok 2016; Breiter et al. 2017). Li-micas from the late Li-granites gave $\mathrm{Ar}-\mathrm{Ar}$ ages in the range between $312.6 \pm 2.1 \mathrm{Ma}$ and $314.9 \pm 2.3$ Ma (Seifert et al. 2011). Molybdenite mineralization in the greisen cupola associated with these late granitic intrusions was dated by the Re-Os system (molybdenite) at $323.9 \pm 2.5 \mathrm{Ma}$ and $317.9 \pm 2.4$ (Romer et al. 2007), and $322.4 \pm 5.5 \mathrm{Ma}, 321.4 \pm 3.8 \mathrm{Ma}, 319.2 \pm 2.0 \mathrm{Ma}$ and $315.3 \pm 2.0$ Ma respectively (Ackerman et al. 2017). The existing geochronological data from the post-TR granitic

Fig. 1a - Location of the Altenberg-Teplice Volcanic Complex (ATVC) among Permo-Carboniferous sedimentary basins and volcanic complexes in the northern part of the Bohemian Massif; $\mathbf{b}$ - Geological setting of the ATVC (AF - Altenberg Fault, LLD - Libkovice-Litvínov dyke; SBDS - Sayda-Berggießhübel dyke swarm; TLH - Teplice-Lahošt' horst); c - Subdivisions of the ATVC volcanic rocks based on Eisenreich and Jeřábek (1978) for the Czech and Lobin (1986) for the Saxon parts. Locations of studied boreholes are shown by stars. 

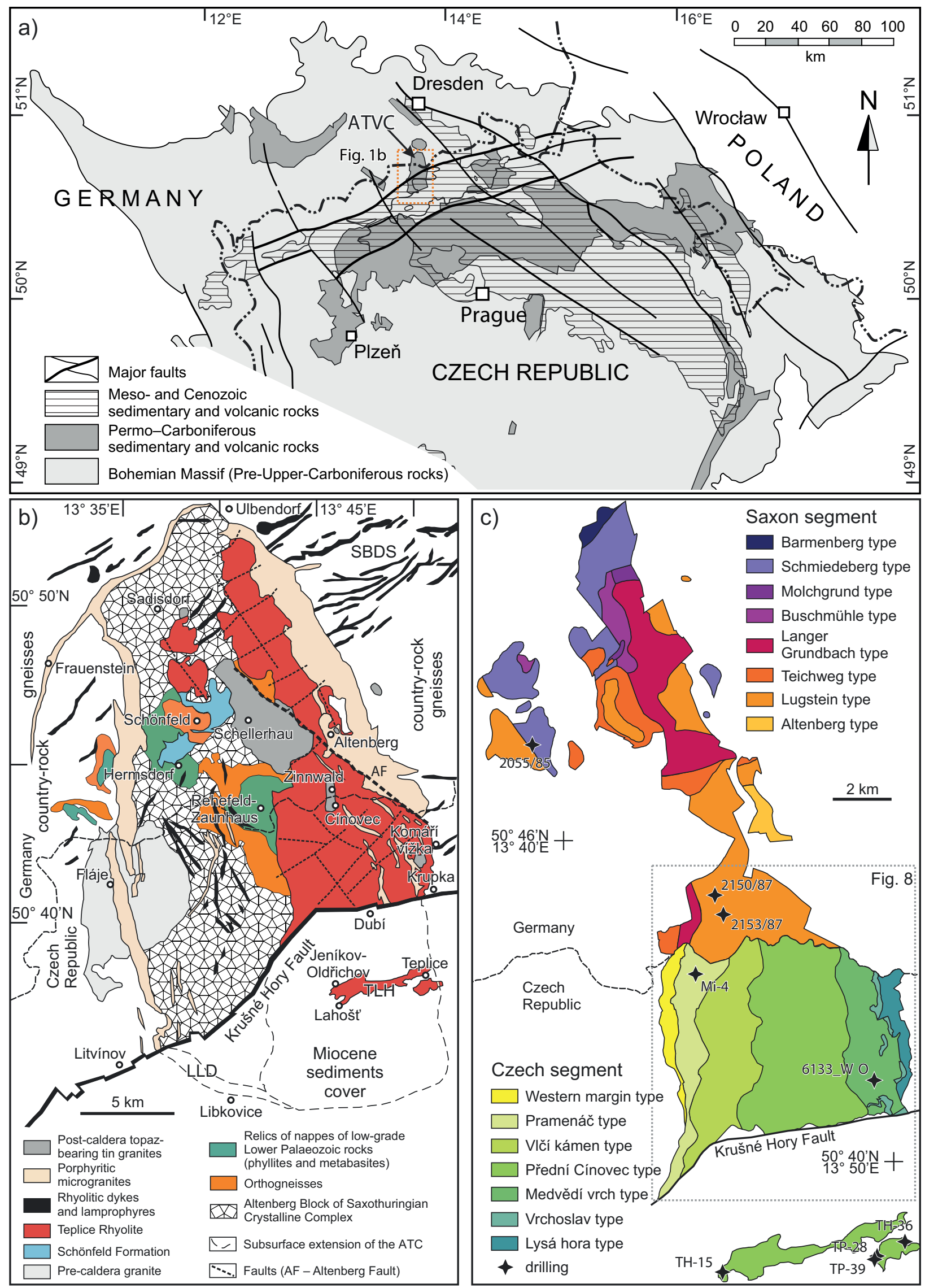
intrusions and related greisens (affecting also the preexisting TR and granite porphyry dykes) indicate that the hiatus between the SADC and TR formation was significantly shorter than suggested by previous palaeobotanic studies (Lobin 1986).

During the Cenozoic, the northern part of the ATC was uplifted along the SW-NE-trending Erzgebirge/ Krušné hory Fault whereas the southern part subsided and is almost completely covered by Mesozoic-Cenozoic sediments (Mlčoch and Skácelová 2010). In addition, ATC is crosscut by the NW-SE trending Altenberg Fault (Fig. 1b), originally only recognized by Tschesnokow et al. (1973). Existence of this prominent fault was later confirmed by evaluation of satellite radar ALOS/PALSAR data (Kopačková et al. 2013).

The ATVC is almost completely surrounded and underlain by various kinds of gneisses. Paragneisses of the Saxothuringian Crystalline Complex occur to the NW and NE of the ATC. The southern part, including the segment buried by the Miocene sediments of the Most Basin, is surrounded by various types of orthogneisses (Hoth et al. 1995; Mlčoch and Skácelová 2010). Erosion exposed paragneisses of the Altenberg Block in the western (lesssubsided) part of the ATC (Fig. 1a). The Altenberg Block at the bottom of the ATC represents a sunken segment of the Saxothuringian Crystalline Complex consisting predominantly of various types of paragneisses. In the less-eroded, subsided Altenberg Block, several relics of nappes of lowgrade Lower Palaeozoic rocks (phyllites and metabasites) are preserved in the central and northern parts of the ATC near to Hermsdorf and Rehefeld-Zaunhaus (Hoth et al. 1995). Rötzler and Plessen (2010) and Pälchen and Walter (2011) described the nappes as a MP-LT Garnet-Phyllite Unit. These nappes also plunge underneath the SADC and represent the upper structural level of the Saxothuringian Zone. The Mi-4 borehole revealed a similar sequence of rocks in the basement of the ATVC (Mlčoch and Skácelová 2010). Intercalations of intensively sheared orthogneisses occur between relict of MP-LT Garnet-Phyllite Unit and the underlying paragneisses (Hoth et al. 1995).

The ATC is almost completely bordered by granite porphyry dykes (ages of $\sim 297 \pm 1$ to $308 \pm 13 \mathrm{Ma}$ : K-Ar and $\mathrm{Ar}-\mathrm{Ar}$ on amphiboles and K-feldspar, respectively: Seltmann and Štemprok 1995; Müller et al. 2005) including the southern, buried part covered by Miocene sediments of the Most Basin (Mlčoch and Skácelová 2010). This ring dyke system includes the almost completely covered Libkovice-Litvínov dyke on the S margin (Mlčoch ed. 1989; Fig. 1b), the Loučná-Fláje dyke on the $\mathrm{W}$ and the Frauenstein and Altenberg dykes on the NW and NE. Besides this ring dyke system, many narrow dykes trending NNW-SSE to NW-SE originated also during the collapse (Wetzel 1984). Dyke swarms mostly trending ENE-WSW to NE-SW occurring outside the caldera are mostly older than the caldera collapse, as indicated by field relations (Wetzel 1984).

\section{Methods}

\subsection{Airborne gamma-ray spectrometry survey}

A new airborne geophysical survey was conducted, which included simultaneously applied gamma-ray spectrometry and magnetometry covering a large area of the eastern Krušné hory Mts. (Czech Republic) in 2011 (Gnojek et al. 2012) and 2013 (Zabadal et al. 2014) complementing the research on the hydrological system of the AltenbergTeplice Caldera within the frame of the project "Reassessment of the groundwater resources" (Burda 2016). An analogous airborne survey was carried out in the neighbouring German part of the Krušné hory/Erzgebirge Mts. in the late 1980's and the early 1990's (Ruhl 1985, 1987, 1990). The data were compiled into new airborne gamma-ray spectrometric maps in 2015.

The parameters used for the survey were: flight line distance of $250 \mathrm{~m}$, perpendicular tie-lines distance about $2500 \mathrm{~m}$, flight speed of $140 \mathrm{~km} / \mathrm{h}$, and ground clearance 80-100 m. Individual measurements were obtained every $40 \mathrm{~m}$ along the flight-lines.

A four-channel gamma-ray spectrometer with 161 of $\mathrm{NaI}(\mathrm{Tl})$ crystals was used in Saxony and a 256-channel gamma-ray spectrometer with 331 of $\mathrm{NaI}(\mathrm{Tl})$ crystals in the Czech Republic. The standard procedure of the airborne gamma-ray spectrometric data processing comprises background subtraction, Compton-scatter correction, atmospheric radon correction, levelling the counts per second to nominal $80 \mathrm{~m}$ ground clearance and transformation of the corrected counts to the concentration of natural radioactive elements, as recommended by IAEA (2003). The resulting geophysical maps are based on $125 \times 125 \mathrm{~m}$ grids of final data created via method of two-dimensional splines. The final gridded data were visualized in element concentration and ratio maps employing Oasis Montaj software (Geosoft).

Individual airborne measurement represents an integrated sum of gamma rays gathered from $\sim 60,000 \mathrm{~m}^{2}$ of the Earth surface within which the total area of outcrop is rather small. The majority of the evaluated area is overlain by weathering products variably saturated by water (marsh, mud, peat, forest-soil) and covered by vegetation, which together attenuate the radiation of the bedrock. Therefore, the radio-element concentrations measured during ground survey on the individual outcrops are often higher. Nevertheless, a comparison of the airborne and the ground gamma-ray spectrometry results showed a very good accordance in terms of concentrations of natural radioactive elements. 


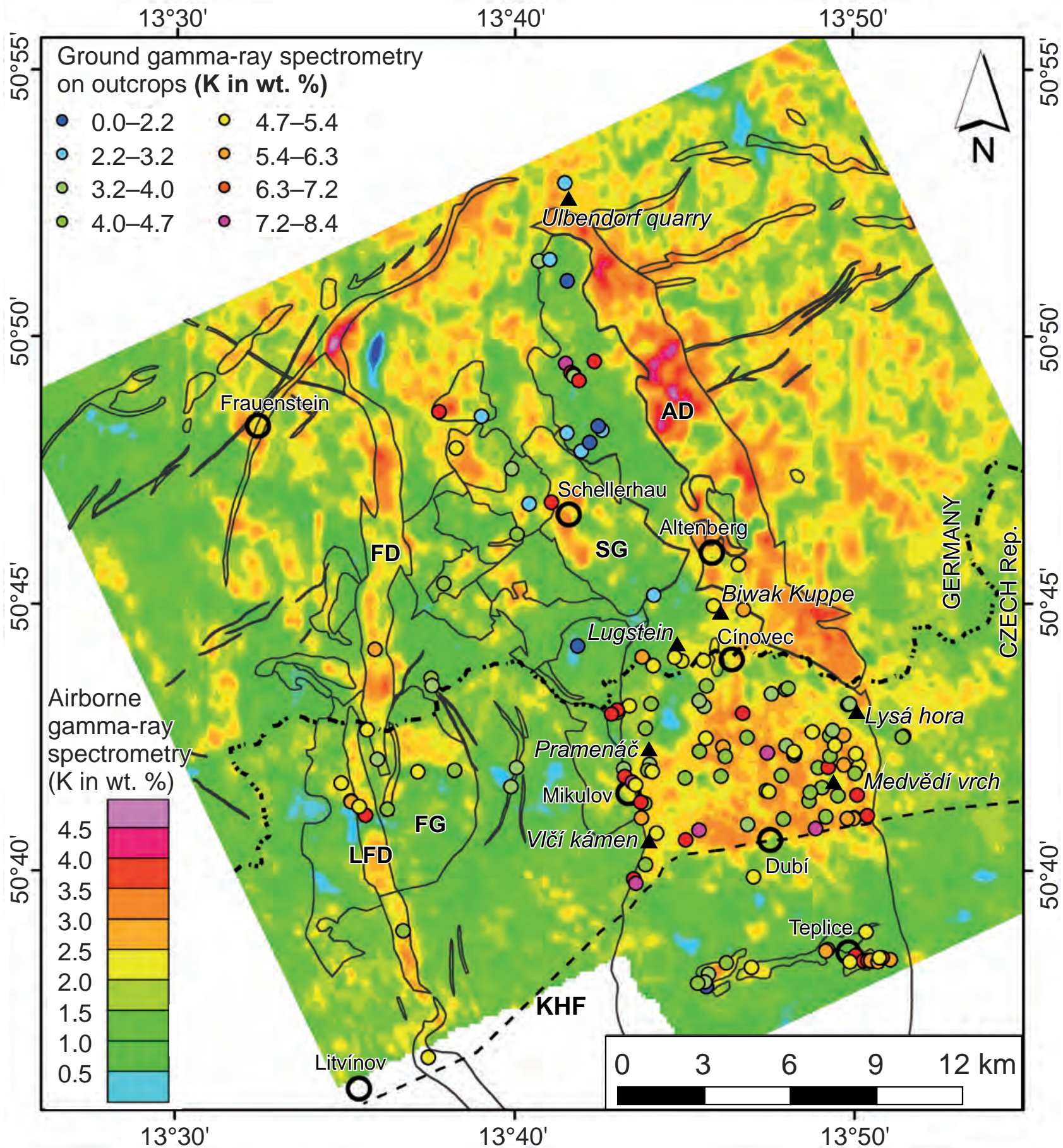

Fig. 2 Airborne-constrained K concentrations, with the mean concentrations obtained by the ground gamma-ray spectrometry. AD - Altenberg dyke (granite porphyry), FD - Frauenstein dyke (granite porphyry), FG - Fláje granite, LFD - Loučná-Fláje dyke (granite porphyry), SG - Schellerhau granite. The outlines of lithologies from Fig. 1b are shown. Dark blue indicates surfaces of large water reservoirs.

Concentrations of mobile $\mathrm{U}$ tend to be modified by post-magmatic processes (e.g., Attia and Wahid 2016; Rihs et al. 2016; Weihermann et al. 2016; Kanzari et al. 2017), and do not reflect the petrology so directly as $\mathrm{K}$ and $\mathrm{Th}$. For that reason, we discuss concentrations of K (Fig. 2), Th (Fig. 3) and Th (ppm)/K (wt. \%) ratio (Fig. 4).

\subsection{Ground gamma-ray spectrometry}

The airborne data were locally supported by in-situ measurements on bedrock outcrops. The concentrations of natural radioactive elements were acquired using a portable gamma-ray spectrometer GRM-256 (GF Instru- 


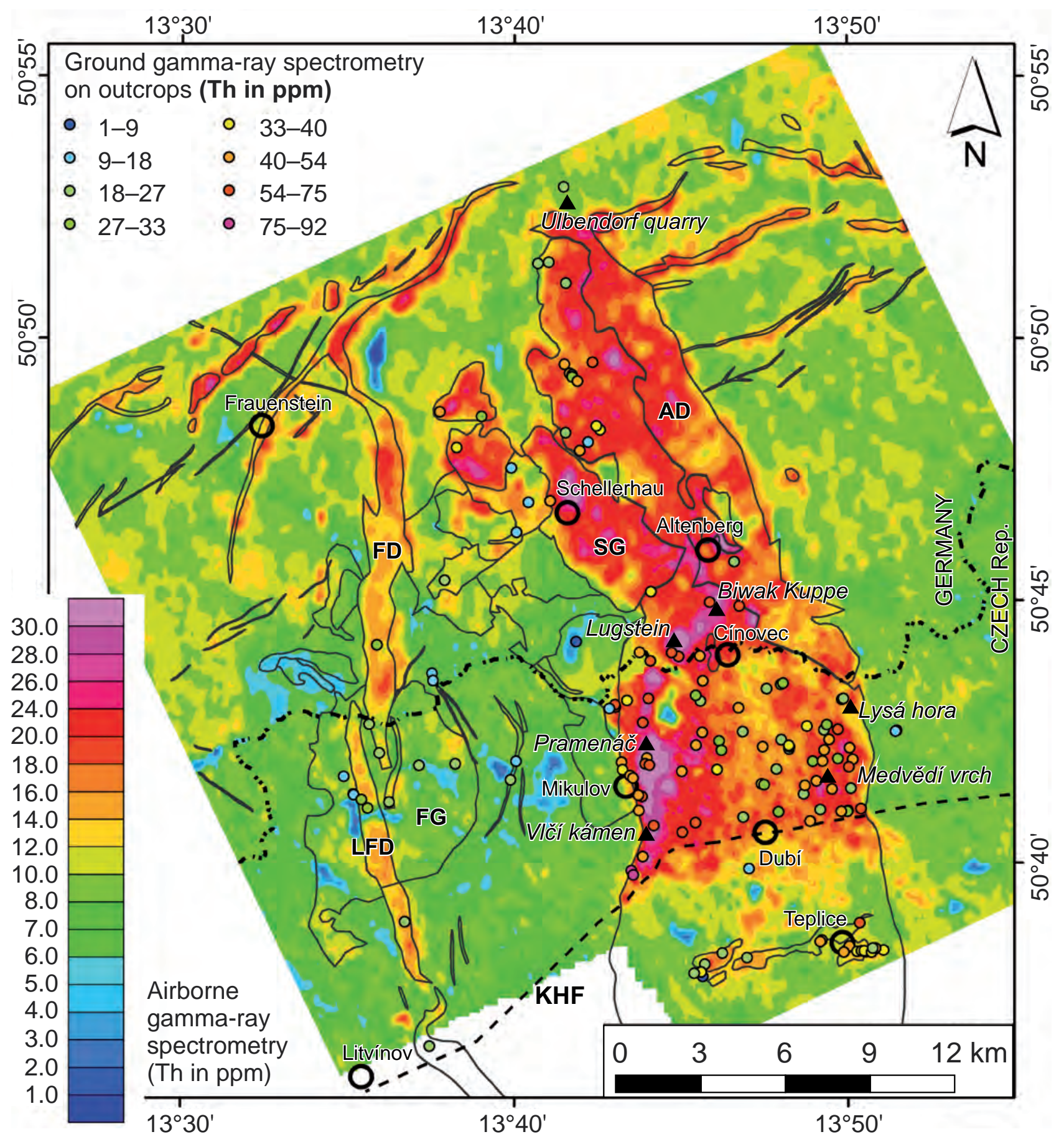

Fig. 3 Airborne-constrained Th concentrations, with the mean concentrations obtained by the ground gamma-ray spectrometry. Abbreviations as in Fig. 2.

ments, Brno) with $103 \mathrm{~cm}^{3} \mathrm{NaI}(\mathrm{Tl})$ detector coupled with a 256 channel spectral analyser.

A three-minute counting time was applied to asure sufficient quality of data (e.g., McCay and Younger 2017). McCay and Younger (2017) recommended more (3-4) repeated measurements if the variation in U concentration between two measurements exceeds $10 \%$. As our study is based mainly on thorium, also variations in
Th concentrations were checked. Most of the outcrops were therefore measured with three repetitions. From the repeated measurements, standard deviations of 0.1 wt. \% K, 0.4 ppm U and 0.6 ppm Th were calculated. Average values for each outcrop are shown in the maps (Figs 2-4), whereas individual measurements are plotted in diagrams (Fig. 5) and listed in Electronic Supplementary Material (Tab. 1). 


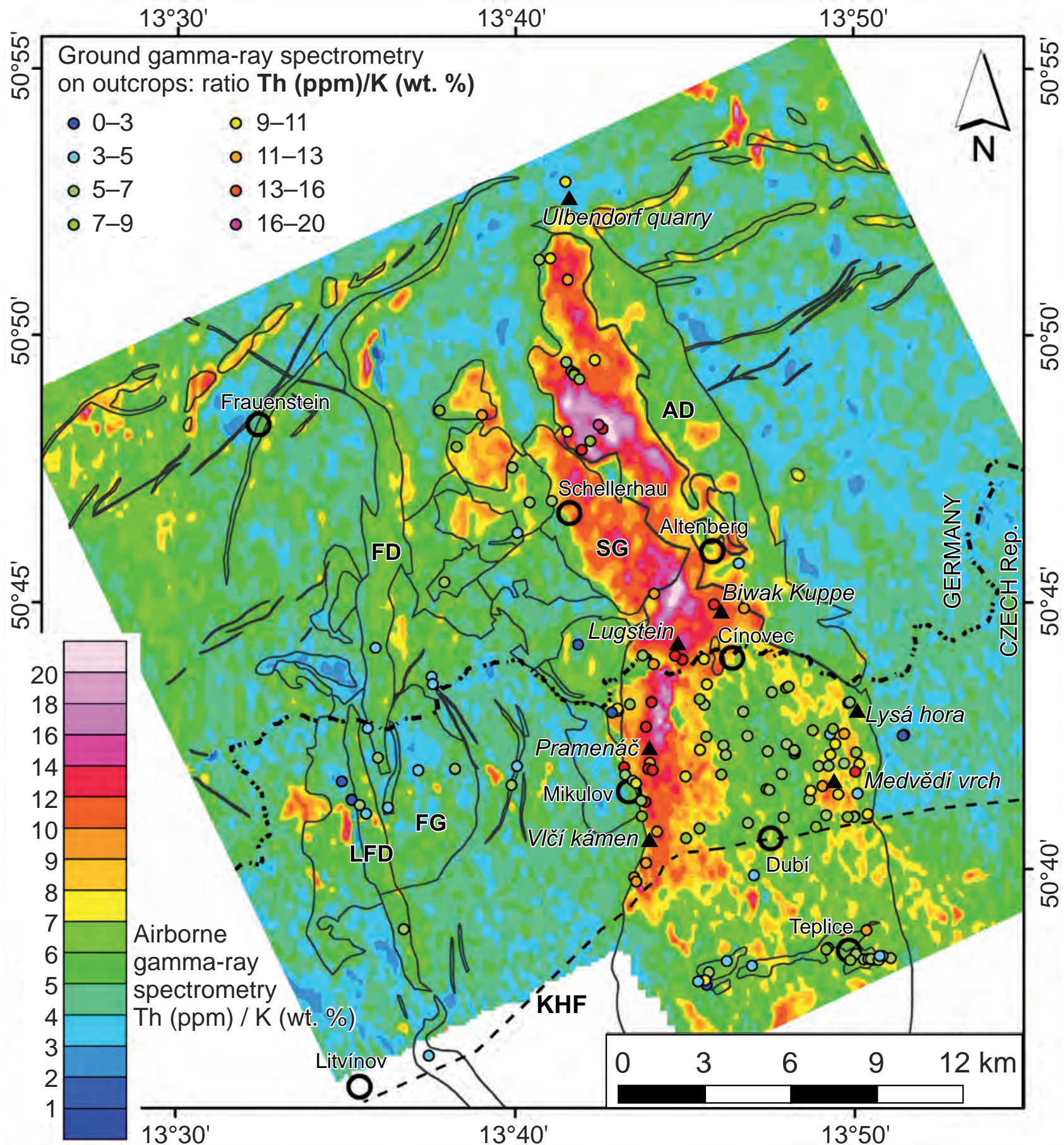

Fig. $4 \mathrm{Th} / \mathrm{K}$ ratio map calculated from the airborne $\mathrm{K}$ and Th concentrations. Abbreviations as in Fig. 2.

\subsection{Laboratory gamma-ray spectrometry}

In addition, samples for laboratory analyses were collected from representative outcrops (Electronic Supplementary Material - Tab. 2), and from drill-cores of selected key-boreholes 2055/85, 2150/87, 2153/87, 6133 WO, Mi-4, TH-15, TH-36, TP-28, TP-39 (see Fig. 1c for location; Electronic Supplementary Mate- rial - Tab. 3). The representative outcrops included type localities for previously defined lithological units, and larger outcrops with clear link to the defined units. The aim of the laboratory analyses was to check the accuracy of the in-situ ground gamma-ray measurements. Laboratory measurements were performed by Georadis Ltd., Brno, Czech Republic using the laboratory gamma-ray spectrometer with a highly reliable 

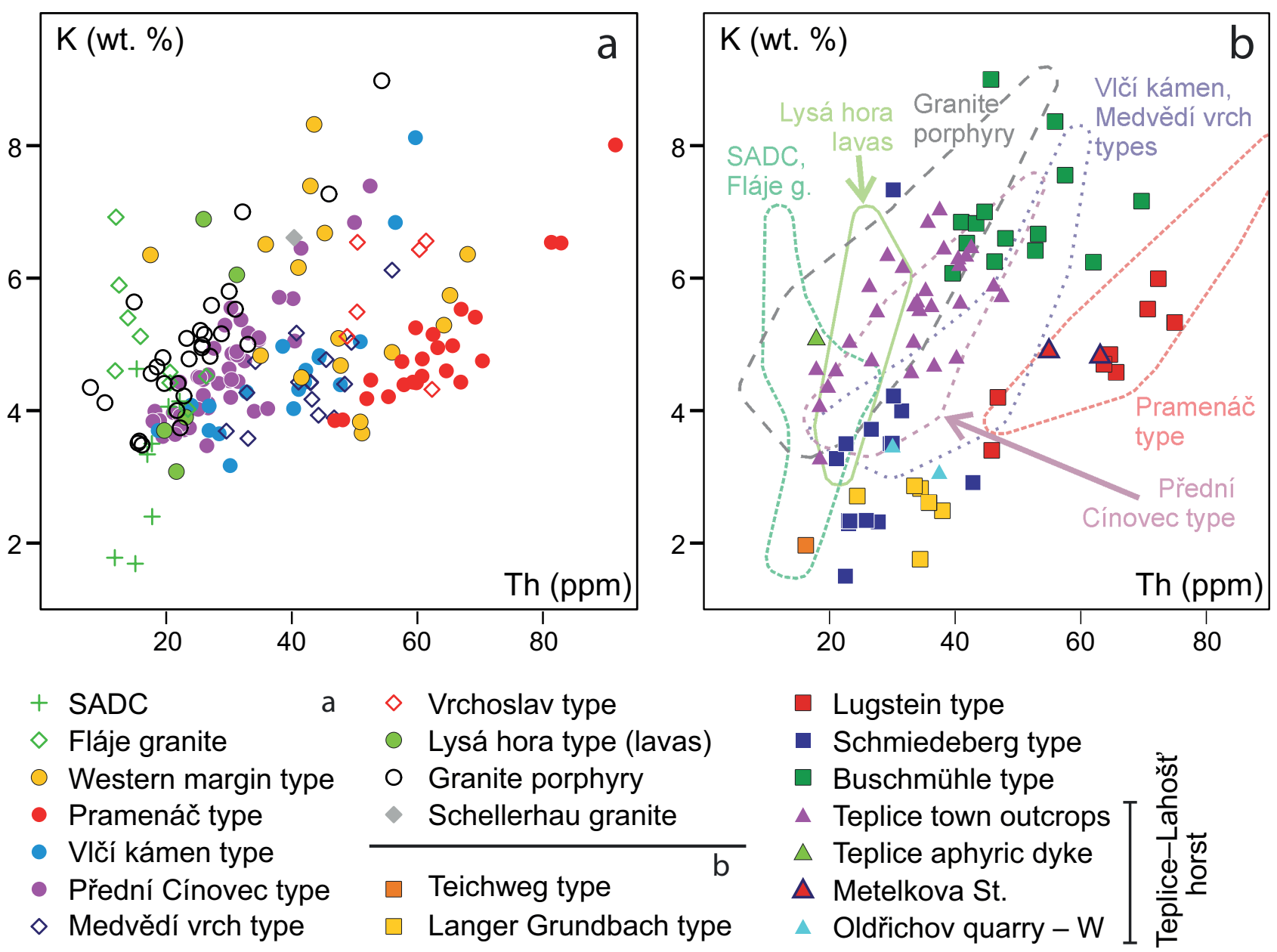

Fig. 5 Binary diagrams Th (ppm) vs. K (wt. \%) for data from: a - Intrusive rocks, SADC, and classified outcrops of the Teplice Rhyolite on Czech side; b - Saxon part and Teplice-Lahošt' horst; fields for the defined types of Teplice Rhyolite on the Czech side (Fig. 5a) are also outlined.

self-contained 1024 channel pulse amplitude analyser and a high-performance $\mathrm{NaI}(\mathrm{Tl})$ scintillation crystal. The laboratory data were used as an independent control of the field results and for correlations between surface and drill-core samples.

\section{Results}

\subsection{Airborne and ground gamma-ray spectrometry of the country rocks and granitic intrusions}

Tab. 1 Concentrations of natural radioactive elements in the country rocks and granitic intrusions of the ATVC

\begin{tabular}{lccccc}
\hline Rock unit & & Method & K (wt. \%) & U (ppm) & Th (ppm) \\
\hline \multirow{2}{*}{ Paragneisses } & outside the caldera & airborne & $1.5-2$ & $2-5$ & $8-12$ \\
& inside the caldera & airborne & $1-2$ & $2-4$ & $7-9$ \\
\hline Micashists with metabasites & & ground & $<1.5$ & $\sim 1.5$ & $<3$ \\
\hline \multirow{2}{*}{ Granite porphyry dykes } & E-branch & airborne & $2.5-4$ & $5-9$ & $16-28$ \\
& & airborne & $2.5-3.5$ & $5-8$ & $14-24$ \\
& W-branch & ground & $4-7$ & $5-14$ & $14-24$ \\
\hline Fláje granite & & airborne & $2-2.5$ & $3-6$ & $8-12$ \\
(Older Intrusive Complex) & ground & $4-7$ & $5-13$ & $20-32$ \\
\hline Schellerhau granite & & airborne & $1.5-2.5$ & $4-9$ & $18-32$ \\
(Younger Intrusive Complex) & & ground & $3-7$ & $5-14$ & $20-40$ \\
\hline \multirow{2}{*}{ Sayda-Berggießhübel dyke swarm } & airborne & $2.5-3.5$ & $6-8$ & $20-28$ \\
& & ground & $3.5-4$ & $9-11$ & $20-36$ \\
\hline
\end{tabular}

Obtained airborne gamma-ray spectrometric patterns of the ATVC show multifarious image with several contrasting rock units (Figs 2, 3 and 4) summarized in the Tab. 1 .

Both the paragneisses outside the caldera and their subsided blocks inside it prove almost equal concentrations of $\mathrm{K}, \mathrm{U}$, and $\mathrm{Th}$. The lowest radioactivity display micaschists with metabasites of Rehefeld-Zahnhaus Complex (Tab. 1).

Granite porphyry dykes bordering almost the whole caldera show noticeable airborne radio- 
active effect, particularly in its thicker eastern branch (Altenberg dyke, Figs 2 and 3). Exceptionally high concentrations c. 8 wt. \% $\mathrm{K}$ and 33-54 ppm Th were measured in the granite porphyry outcrops with rapakivi texture (Ulbendorf quarry - Fig. 1b).

The Fláje granite (Older Intrusive Complex, S-type) has lower concentrations of $\mathrm{K}, \mathrm{U}$ and Th in the airborne maps. Its real radioactivity is attenuated by a large cover of water-saturated Quaternary deposits - marshes and peat bogs. Rare in-situ measurements prove higher concentrations such as $4-7$ wt. $\% \mathrm{~K}, 5-13 \mathrm{ppm} \mathrm{U}$, and $12-25 \mathrm{ppm}$ Th.

While the K concentrations in the Schellerhau granite (Younger Intrusive Complex, A-type) are rather low (1.5-2.5 wt. \% K for the fine-grained and $2-4$ wt. $\% \mathrm{~K}$ for the medium-grained type), the $\mathrm{U}$ and Th contents reach 4-9 ppm U and 18-32 ppm Th regardless of grain-size. Several in-situ measurements corroborated these increased concentrations (3-7 wt. \% $\mathrm{K}, 5-14 \mathrm{ppm} \mathrm{U}$ and 20-40 ppm Th) and confirmed higher concentrations of potassium in the mediumgrained granite.

Sayda-Berggießhübel dyke-swarm - mostly ENEWSW trending rhyolite and lamprophyre dykes (Older Intrusive Complex; Wetzel 1984; Winter et al. 2008; Fig. 1b) - comprises strongly radioactive rocks. Its response in the airborne maps is controlled by the thickness of individual dykes. Exceptionally low content of Th ( 10 ppm) was found at Komáŕí Vížka $\mathrm{N}$ of the town of Teplice (Figs $1 \mathrm{~b}$ and 3).

\subsection{Airborne and ground gamma-ray spectrometry in the Czech segment of the Teplice Rhyolite}

Rhyolite ignimbrites and subordinate lavas (Teplice Rhyolite - TR) occupy a significant portion of the caldera. They form a belt, in the southern (mostly Czech) part up to $8 \mathrm{~km}$ and in Germany only $\sim 3 \mathrm{~km}$ wide in the E-W direction. Several distinct domains with distinct concentrations of radioactive elements were recognized in the southern segment of the ATVC (Sedlák et al. 2014; Figs 2-4), which can be correlated with lithological types sensu Eisenreich and Jeřábek (1978; see Fig. 1c; Tab. 2) as follows. From west to east they are:

(a) A narrow wedge of rhyolite ignimbrites with airborne measured concentrations of 1.5-2 wt. \% K (Fig. 2), 4-6 ppm U and 14-18 ppm Th (Fig. 3) that corresponds to the extent of the Western margin type.

(b) A 1-2 km wide segment of rhyolite ignimbrites with the highest concentrations of $\mathrm{K}(2-2.5$ wt. \%), U (7-17 ppm), and Th (26-34 ppm) corresponding to the Pramenáč type.
Tab. 2 Concentrations of natural radioactive elements in the individual types of the Teplice Rhyolite

\begin{tabular}{lccccc}
\hline Lithological type & Method $\mathbf{K}(\mathbf{w t} . \mathbf{\%})$ & $\mathbf{U}(\mathbf{p p m})$ & Th $\mathbf{( p p m )}$ & $\mathbf{n}$ \\
\hline \multirow{2}{*}{ Western margin } & airborne & $1.5-2$ & $4-6$ & $14-18$ & \\
& ground & $3.5-8.5$ & $6.5-16$ & $35-50$ & 9 \\
\hline \multirow{2}{*}{ Pramenáč } & airborne & $2-2.5$ & $7-17$ & $26-34$ & \\
& ground & $3.5-6$ & $17-27$ & $48-83$ & 16 \\
\hline \multirow{2}{*}{ Vlčí kámen } & airborne & $2-2.5$ & $7-17$ & $20-28$ & \\
\multirow{2}{*}{ Přední Cínovec } & ground & $4-5.5$ & $6.5-8$ & $39-60$ & 17 \\
& airborne & $2-3.5$ & $5-7$ & $14-18$ & \\
\multirow{2}{*}{ Medvědí vrch and Vrchoslav } & ground & $2.8-5.5$ & $17-27$ & $18-40$ & 60 \\
& airborne & $1.7-2.5$ & $6-10$ & $14-24$ & \\
& ground & $3.8-5.5$ & $8-14$ & $40-53$ & 14 \\
\hline \multirow{2}{*}{ Lysá hora } & airborne & $1.5-2.5$ & $4-5$ & $12-20$ & \\
& ground & $3-4$ & $7-9$ & $20-26$ & 4 \\
\hline
\end{tabular}

- number of measurements

(c) About $2 \mathrm{~km}$ wide belt of rhyolite ignimbrites with 2-2.5 wt. \% K, 7-17 ppm U and 20-28 ppm Th (in airborne maps) correlates with the Vlčí kámen type. Ground measurements found locally unusually wide ranges of the K, U and Th concentrations. Surprisingly, the type locality Vlčí kámen hill lies within the belt of high-Th rocks (Pramenáč type, Fig. 3), out of the belt of Vlčí kámen type.

(d) A $3 \mathrm{~km}$ wide segment of generally low concentrations of radioactive elements corresponds to Přední Cínovec type.

(e) A 2-3 km wide segment with the highly disturbed pattern due to frequent intrusions of post-ignimbrite granite porphyry dykes belongs to the types of Medvědí vrch and Vrchoslav. The Vrchoslav type is exposed only in a small isolated outcrop, which does not allow to characterize this type on the basis of the airborne survey. Three measured outcrops of the Vrchoslav type showed high concentrations of $\mathrm{K}$ (4.5-6.5 wt. \%), U (8-14 ppm), and Th (49-62 ppm).

(f) A narrow wedge with relatively low airbornemeasured concentrations of $\mathrm{K}, \mathrm{U}$ and Th corresponds to lavas of the Lysá hora type.

The rhyolitic ignimbrites cropping out in the TepliceLahošt' horst (Fig. 1b) were formerly assigned wholly to the Přední Cínovec type (Fig. 1c). Exceptionally high U concentrations (up to $105 \mathrm{ppm}$ ) were observed in the rhyolite ignimbrites exposed in the Jeníkov-Lahošt' elevation (the westernmost edge of the Teplice-Lahošt' horst, $4 \mathrm{~km} \mathrm{WSW}$ of the town of Teplice), that were affected by post-emplacement $\mathrm{Ba}-\mathrm{U}$ mineralization (Zachariáš et al. 2008). Apart from this anomaly, most of the horst has a uniform composition with 5-8 and 8-16 ppm U (airborne and ground respectively).

The airborne and ground gamma-ray data for $\mathrm{K}$ and $\mathrm{Th}$ suggest presence of several separate units within the horst. Its western part is characterized by lower concentrations of $\mathrm{K}$ (2-3 wt. \% airborne and $3.2-5$ wt. \% ground) and higher 
concentrations of Th (14-20 ppm airborne and 18-34 ppm ground). The central part has very low airborne-evidenced concentration of $\mathrm{K}(\sim 1 \mathrm{wt} . \%)$ contrasting with moderate ground-measured values (5.6-5.8 wt. \%). Airbornemeasured Th concentrations in the central part ( $8-14 \mathrm{ppm})$ are lower than those obtained by ground survey (40-47 $\mathrm{ppm})$. The easternmost part has again higher contents of $\mathrm{K}$ (1.5-2.5 wt. \% airborne and 4.6-6.6 wt. \% ground), U (9-13 ppm airborne and 8-26 ppm ground) and Th (12-16 ppm airborne and 19-60 ppm ground).

However, in this Teplice-Lahošt' horst significant differences occur between the airborne- and groundmeasured concentrations. They are caused by dissimilar weathering cover, different surface-geometry (small abandoned quarries) of the radioactive sources and diverse quantity of moisture between the mountain and the basin settings.

Accordingly, lower concentrations can be obtained on sites with poor outcrop conditions, but the ratio between radioactive elements should remain unchanged. Therefore, the $\mathrm{Th} / \mathrm{K}$ ratio map of airborne data was constructed (Fig. 4), and ground measurements were plotted in Th vs. K binary diagram (Fig. 5). The contents of Th and $\mathrm{K}$ in intrusive rocks, SADC and Czech types of the Teplice Rhyolite are shown in the Fig. 5a. The Fláje granite and SADC are characterized by low contents of both $\mathrm{K}$ and Th. The individual types of Teplice Rhyolite are then arranged by decreasing $\mathrm{Th} / \mathrm{K}$ ratio (from right to left): Pramenáč type, Vlčí kámen and Medvědí vrch types together, Přední Cínovec type, and granite porphyry (microgranite) dykes together with Schellerhau granite and Lysá hora type lavas. Data from the Western margin type are widely dispersed across all defined types. Few

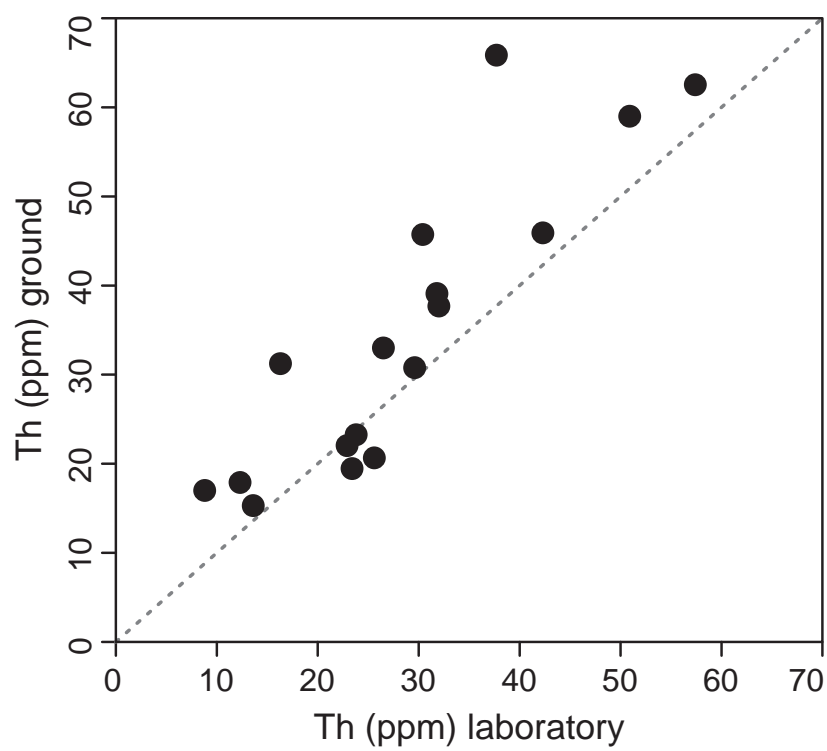

Fig. 6 Test of the data consistency between concentrations of thorium measured by in-situ ground gamma-ray spectrometry and laboratory gamma-ray spectrometry. measurements from the Vrchoslav type plot in different parts of the diagram, into domains typical for Pramenáč type and Vlčí kámen and Medvědí vrch types. This may be due to complicated tectonic situation on the eastern margin of the ATVC that complicates the identification of individual Vrchoslav type ignimbrite outcrops.

The data from the Teplice-Lahošt' horst can be subdivided into four distinct groups (Fig. 5b). Most of the data correspond to the Přední Cínovec type. Two measurements from the Metelkova Street in the easternmost part of Teplice Town fall into the field of "Pramenáč" type, and two measurements from the western part of the Oldřichov quarry most likely correspond to the Vlčí kámen type. The small outcrop of aphyric dyke in Teplice (řetenice, sample TR13 in Electronic Supplementary Material - Tab. 1) shows similar values to those of Lysá hora type lavas.

\subsection{Airborne and ground gamma-ray spectrometry in the Saxon segment of the Teplice Rhyolite}

Geological and gamma-ray patterns of the Czech part are comparable only with the southernmost Saxon part of the ATC, i.e. between the state border and the NW-SE trending Altenberg Fault (Fig. 1b). Three belts can be distinguished here. The belt with low airborne-obtained concentrations of K ( $\sim 1$ wt. \%), U (3-4 ppm) and Th (14-24 ppm) with a single ground-measured outcrop (K 2.9 wt. \%, U $5.5 \mathrm{ppm}$ and Th $34 \mathrm{ppm}$ ) corresponds to the mapped Langer Grundbach type (Fig. 1c). The type Teichweg that should crop out to the west of the Langer Grundbach type cannot be identified from the airborne gamma-ray data. On the other hand, the type Lugstein mapped with large aerial extent to the east can be further subdivided into two parts. The western part that hosts outcrops on Lugstein and Biwak Kuppe shows slightly increased K (1.5- 2.5 wt. \% airborne and 4.9-5.5 wt. \% ground), and particularly high U (6-8 ppm airborne and $18-21 \mathrm{ppm}$ ground) and Th (22-32 ppm airborne and $64-70 \mathrm{ppm}$ ground). The eastern part of Lugstein differs by higher concentration of $\mathrm{K}$ ranging 2-3 wt. \% in airborne data (single outcrop gave ground-measured value of 6 wt. \%), but slightly lower contents of U (3-7 ppm airborne and $22 \mathrm{ppm}$ ground) and Th (20-24 ppm airborne and $72 \mathrm{ppm}$ ground).

To the north of the Altenberg Fault, the rhyolite belt, together with two isolated erosional remnants (NW of Schellerhau), distinctly differ from the southern one. The individual rhyolite types defined by Lobin (1986; Fig. 1c) do not appear in continuous areas, but they are scattered over several separated places often of very small size (Lugstein in seven, Teichweg in six and Schmiedeberg type in five such spots; Fig. 1c), most likely representing 
erosional remnants. Moreover, individual occurrences of the same mapped lithotype situated on different places differ in gamma-ray image (Figs 2-4).

Combining airborne data and ground measurements reveals that the dispersed Lugstein type in the Saxon segment has higher concentrations of Th (26-30 ppm airborne) and variable contents of K (Figs 2-4). The Lugstein type, together with the occurrences of the Langer Grundbach and the Buschmühle types, can be qualified as rhyolites of moderately but still distinctly increased radioactivity containing $1.0-2.5$ wt. $\% \mathrm{~K}, 3-6 \mathrm{ppm} \mathrm{U}$ and 16-24 ppm Th (airborne). Remaining rhyolite types such as the Schmiedeberg, Teichweg and Barmenberg demonstrate the lowest radioactivity among the rhyolites in Saxony (carrying only c. $1-2$ wt. $\% \mathrm{~K}$, mostly $\sim 3 \mathrm{ppm}$ $\mathrm{U}$ and $14-22 \mathrm{ppm} \mathrm{Th}$ ).

To the west of Schellerhau, volcanic rocks of the Schönfeld-Altenberg Depression Complex (SADC; Walther et al. 2016) crop out in two areas (Fig. 1b). The SADC rocks are characterized by lower contents of natural radioelements if compared to any type of the Teplice Rhyolite. The airborne-obtained concentrations vary $1-2.5$ wt. $\%$ for $\mathrm{K}, 3-7 \mathrm{ppm}$ for $\mathrm{U}$ and $8-20 \mathrm{ppm}$ for Th. These data were confirmed by ground gamma-ray measurements on four outcrops with 3-4.6 wt. \% K, 8-17 ppm U, and 15-21 ppm Th (see also Fig. 5a).

The contents of Th and K obtained from in-situ ground gamma-ray spectrometry are plotted in binary diagram (Fig. 5b), where these are compared with fields defined for Czech lithotypes. The data from the Lugstein type match the field of Pramenáč type. Teichweg, Langer Grundbach and Schmiedeberg types make together one cluster at low concentrations of both Th and $\mathrm{K}$, not comparable to any type from the Czech side. Similarly, Buschmühle type differs from any type on the Czech side, in this case by having high $\mathrm{K}$ concentrations at variable Th contents (Fig. 5b).

\subsection{Vertical compositional variability in boreholes}

The Altenberg-Teplice Caldera hosting sequences of rhyolitic ignimbrites was also subject of intensive drilling surveys focused on resources of Mo, W, Sn, Li, U and thermal water. As the ignimbrites are deposited subhorizontally or dipping at low angles, individual types should be identified and correlated among individual drillings also across the state border. In total, drill-core samples from nine boreholes were subject to laboratory gamma-ray spectrometry analysis. The comparability of ground (in-situ) and laboratory gamma-ray measurements can be tested on a binary diagram comparing concentrations of Th obtained by both methods from several outcrop samples (Fig. 6). The data plot close to the 1:1 line, suggesting a good agreement between both methods. Moreover, the results of the drill-core analyses are plotted against depth and the drillings are arranged from NNW towards SSE (Fig. 7).

The Mi-4 borehole on the Czech side of the state border penetrated almost the complete sequence of the western part of the ATC. The volcanic units here are labelled according to Breiter et al. (2001) from top to bottom TR3a (= Pramenáč type), TR2b, TR2a, TR1 and SADC. The unit TR2b is similar to the Western margin type and the latter three units do not crop out on the Czech territory. TR3a (= Pramenáč type) is characterized by high (>60 ppm) contents of Th, separated by significant drop in Th contents from underlying TR2 $b$ (probably Western margin type, c. $40 \mathrm{ppm} \mathrm{Th}$ ). The underlying units TR2a and TR1 have variable contents of Th (20-60 ppm) and may correspond to Teichweg type defined in Saxony. The lower part of the drill core consists of dacitic rocks of the SADC with extremely low Th concentrations $(<20 \mathrm{ppm}$; Walther et al. 2016).

The profile of the Mi-4 drilling can be compared to the nearby German drillings 2150/87 and 2153/87 with incompletely preserved drill-cores. In these drillings, SADC rocks are overlain directly by high-Th Lugstein type (2150/87) or by more complete sequence comprising also units with concentrations of radioactive elements similar to TR1 and TR2b units (2153/87). Two petrological types were described from reduced thickness of the Teplice Rhyolite $(100 \mathrm{~m})$ in the drilling $2055 / 85$. The upper $70 \mathrm{~m}$ represent Lugstein type and the lower $30 \mathrm{~m}$ correspond to Schmiedeberg type (Walther 2013). The contrasting lithologies are not reflected in the gammaray profile of the drill-core with variable but moderate concentrations of Th, similar to those from TR2a and/or TR2b (Fig. 7), and even in the upper part far below the common concentrations observed in the Lugstein type elsewhere.

The Přítkov 6133_WO borehole (total depth $161 \mathrm{~m}$ ) situated in the eastern part of the ATC was drilled through a single unit (Medvědí vrch type) with Th contents $<60$ ppm.

The boreholes in the Teplice-Lahošt' horst (TH-15, TP-39, TP-28, TH-36) differ from the Krušné hory/Erzgebirge part of the ATVC. The complete length of all four analysed drill cores (TP-39 has 1170 m; Cuř́n et al. 1989) is characterized by homogeneous composition with rather low Th contents $(20-40 \mathrm{ppm})$ pointing to the presence of a single lithological type of TR ignimbrite.

\section{Discussion}

Among the natural radioactive elements, the relatively immobile Th seems to be the best lithological indicator (e.g., 
NW

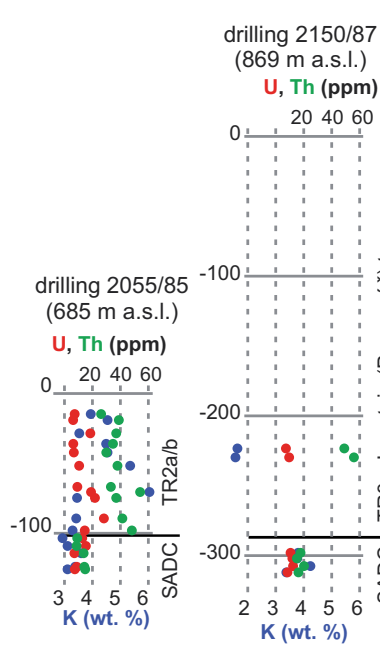

Krušné hory/Erzgebirge area
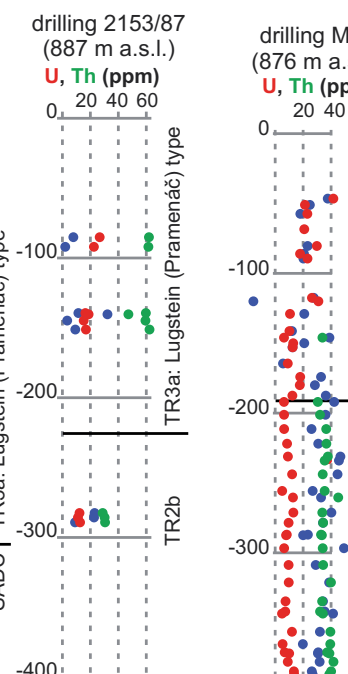

: :

:

$-300$ drilling Mi-4

(876 $\mathrm{m}$ a.s.l.)

204060

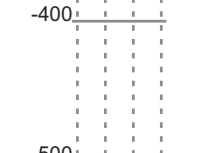

:

$-100+\frac{\pi}{0}$

a

(-

(O)

$\begin{array}{lll} & \text { drilling } \\ 0 & 0 & 0\end{array}$

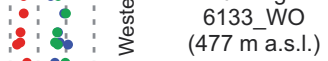

$\begin{array}{c:cc}0 & \text { U, Th (ppm) } \\ 0 & 0 & 04060\end{array}$

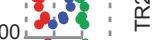

$$
0
$$

\begin{tabular}{c:cc}
0 & 0 \\
0 & 0 & 1 \\
\hdashline & 0 & 1
\end{tabular}

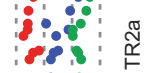

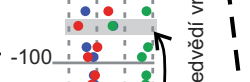

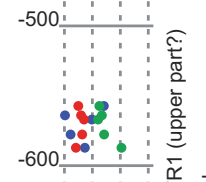

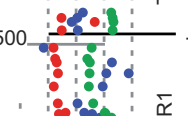

1
1
1

- $\begin{array}{c:cc}0 & \sum_{0} & 1 \\ 0 & 0 & 1\end{array}$

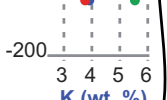

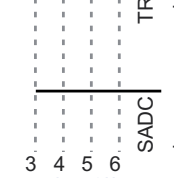

a

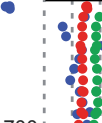

$\begin{array}{c:cc}3456 \\ \quad & \mathrm{~K} \text { (wt. \%) }\end{array}$

porphyry
dyke

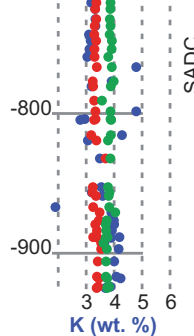

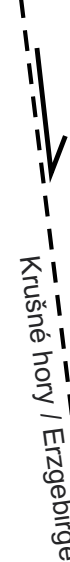

Teplice-Lahošt' horst (Most Basin) area

SE

rilling $\mathrm{TH}-15$

(229 $\mathrm{m}$ a.s.l.) drilling TP-39 drilling TP-28

U, Th $(\mathrm{ppm}) \quad(222 \mathrm{~m}$ a.s.l.) $\quad(222 \mathrm{~m}$ a.s. I.)

$(222 \mathrm{~m}$ a.s.I.)
U, Th (ppm)
$0 \quad 204060$

drilling $\mathrm{TH}-36$

$208 \mathrm{~m}$ a.s.l.)

:

204060
$0 \quad \quad 1$

\begin{tabular}{lll}
\hline & 1 & 1 \\
\hline & 1 & 1 \\
1 & 1 & 1 \\
& 1 & 1 \\
\hline & 0 & 1
\end{tabular}

, Th (ppm)

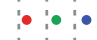

$-100-100$

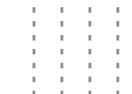

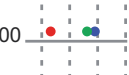

:

$-100$

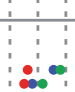

\begin{tabular}{ccc}
0 \\
$3456-200$ \\
\hline 3400
\end{tabular}

K (wt. \%)

200

$\because:$

$\begin{array}{lll}-200 & \vdots \\ 0 & 0\end{array}$

0
0

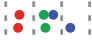

-100

:

$-200 \cdot \bullet$

$\begin{array}{llll}3 & 4 & 5 & 6\end{array}$

K (wt. \%)

- $\mathrm{K}$ (wt. \%) - scale at the bottom of each drilling

- $U(\mathrm{ppm})$ - scale at the top of each drilling

- Th (ppm) - scale at the top of each drilling

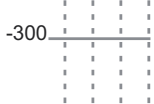

$-300 \quad$

$-400$

$-400$

$-500$

\begin{tabular}{l}
1 \\
\hline \\
\hline
\end{tabular}

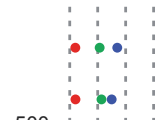

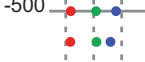

-

$-600$

$-600$

$\bullet \bullet$,

" • " •"

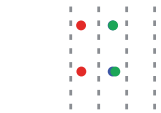

$-700$

(1)

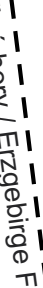

1.

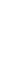

$-700$

$-800$

$-800$

a

:

-900:

$-900$

䒿।

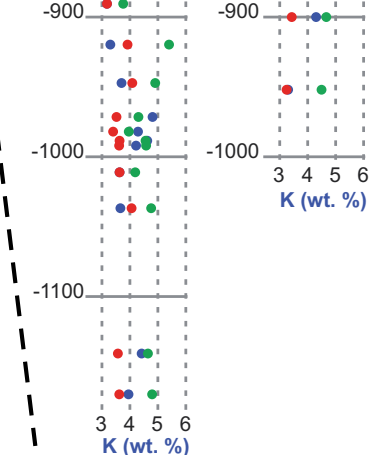

Fig. 7 Distribution of K, Th and U (measured in laboratory) with depth in the studied drill-cores of Teplice Rhyolite ignimbrites. Note the shift in altitudes between the mountain and basin areas due to vertical offset on the Krušné hory Fault.

Breiter et al. 1998 in the Moldanubian Pluton; Leichmann et al. 2016 in the Třebíc durbachite Pluton). The use of U in petrological studies is limited because of its solubility and mobility (e.g., Attia and Wahid 2016; Rihs et al. 2016;
Weihermann et al. 2016; Kanzari et al. 2017). The distribution of potassium can contribute to lithological studies but it might also indicate rock alterations accompanying ore-bearing processes (Gnojek and Přichystal 1985). 
Remarkable patterns of natural radioactivity (based on regular and detailed data grids of the airborne survey) provide a useful tool in delineation and correlation of both eruptive and intrusive bodies of the ATVC. They are caused by different abundances of the $\mathrm{K}, \mathrm{U}$ and $\mathrm{Th}$ and, consequently, by different ratios of these elements. In our case the $\mathrm{Th} / \mathrm{K}$ ratio was applied.

Four major stages took place during the Altenberg-Teplice Caldera evolution (see also Geological setting) for which distinct gamma-ray characteristics can be defined:

(a) emplacement of the Fláje Massif (Older Intrusive Complex, unknown age), and SADC ( $326 \mathrm{Ma})$ both with low contents of Th and $\mathrm{K}$;

(b) eruptions of rhyolitic lavas and ignimbrites (Teplice Rhyolite, $\sim 320 \mathrm{Ma}$ ), in southern part with Th contents decreasing towards the centre of the ATVC;

(c) intrusion of the microgranite (granite porphyry, uncertain age) dykes with high $\mathrm{K}$ and low Th contents;

(d) intrusion of the Schellerhau granite and Cínovec Li-granites $(\sim 312 \mathrm{Ma})$ with radioactive element contents similar to those of granite porphyry dykes.

The Sayda-Berggießhübel dyke system comprises several WSW-ENE trending dyke swarms of at least three generations (Wetzel 1984; Winter et al. 2008) with distinct contents of radioactive elements, notable in the $\mathrm{K}$, and especially in the Th concentration map (Figs 2 and 3 ).

Fig. 8 Proposed correlation between the Czech and Saxon lithological types of the ATVC south of the Altenberg Fault on the Th distribution map. AD - Altenberg dyke, LH - Lysá hora lavas. See Fig. 3 for colour legend.

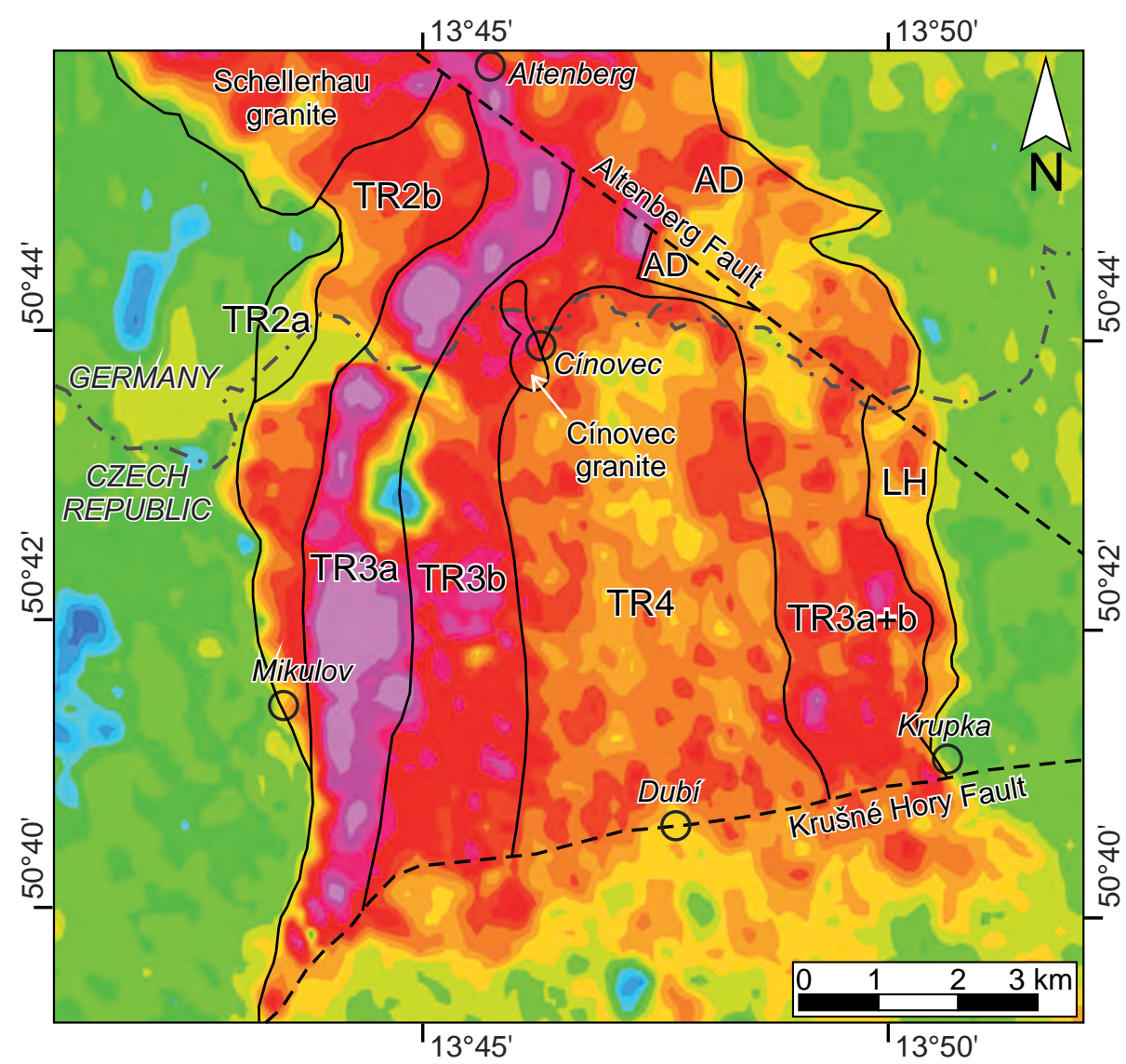

Significant compositional differences identified among the individual types of the ATVC can be used for crossborder correlations. Based on the similarities of radioelement concentrations and continuity of belts with the same gamma-ray properties, a table and a sketch-map correlating units defined in Mi-4 drilling (Breiter et al. 2001) with mapped types (Eisenreich and Jeřábek 1978; Lobin 1986) are presented (Tab. 3, Fig. 8). 
Comparably high Th contents of the Pramenáč and Lugstein types (Fig. 5b) forming a continuous belt (Fig. 3), together with similar petrographical characteristics (highly welded ignimbrites, rich in large crystal clasts), suggest that they represent a single unit (TR3a), which can be followed in isolated remnants also north of the Altenberg Fault.

The belt to the west of TR3a (Pramenáč/Lugstein) has, again, similar airborne gamma-ray characteristics on both sides of the border (Figs 2-4), although the groundmeasured values differ. The higher concentrations of both $\mathrm{K}$ and Th on the Czech side (Western margin type) compared to the Saxon part (Langer Grundbach type) reflects the fact that rocks are less altered and better exposed on the Czech side, as the $\mathrm{Th} / \mathrm{K}$ ratio remains stable (Fig. 7). This belt can be assigned to the TR2b unit defined in the Mi-4 drilling (sensu Breiter et al. 2001, Fig. 5). The Teichweg type underlying the TR2b unit is not known from outcrops in the Czech part of the ATVC, but it seems that it could represent the TR2a unit in the Mi-4 drilling. At this moment, the TR1 unit known from the Mi-4 drilling cannot be correlated to any superficially outcropping lithological type.

On the other hand, the identical concentrations of Th and $\mathrm{K}$ in the Vlčí kámen and Medvědí vrch types, and the eastern part of the Lugstein type, suggest that these types can be merged into a single unit TR3b, characterized by moderate Th contents (Fig. 8). The position of the Vrchoslav type remains somewhat uncertain because its thickness is tectonically reduced and disturbed by numerous post-ignimbrite granite porphyry dykes. From its position, we suggest that this type might represent an equivalent of TR3a (Pramenáč and Lugstein types), but only a single measurement from the Vrchoslav type fits into the field of Pramenáč type in the Th vs. K diagram (Fig. 5a).

The TR3b unit is surrounding the central part of the ATVC represented by Přední Cínovec type, which is the youngest ignimbrite unit known in the ATVC. Such presumption is supported by close compositional relations ( $\mathrm{K}$ and $\mathrm{Th}$ ) between Přední Cínovec type and post-ignimbrite granite porphyry dykes (Fig. 7). Breiter et al. (2001) termed this unit TR3c, but the gamma-ray spectrometry data show closer similarity of the Přední Cínovec type to the granite porphyry dykes than to the previous ignimbrite units. Therefore, a new label TR4 is proposed here, better expressing its compositional difference from TR3a and TR3b.

The low-Th belt on the eastern margin of the ATVC corresponds to the Lysá hora type, defined as aphyric rhyolitic lavas (Jiránek et al. 1987). These lavas have similar contents of radioactive elements as the TR4 (Přední Cínovec type) and may represent the final eruptive stage of the ATVC temporally related to the emplacement of granite porphyry dykes and TR4 ignimbrite.
The younger magmatic stage, postdating the eruptions of the Teplice Rhyolite, is represented by the Schellerhau granite intrusion (312.6 $\pm 2.1 \mathrm{Ma}$ to $314.9 \pm 2.3 \mathrm{Ma}$ : ArAr on Li-mica; Seifert et al. 2011) and it is characterized by rather ordinary or moderately increased contents of $\mathrm{K}$ accompanied by very high abundances of $\mathrm{U}$ and $\mathrm{Th}$. Consequently, the $\mathrm{Th} / \mathrm{K}$ ratio values on the Schellerhau granite reach $8-14 \times 10^{-4}$.

The rim of the granite porphyry limiting almost the whole ATC has distinct abundances of $\mathrm{K}$ and remarkably high concentrations of $\mathrm{U}$ and $\mathrm{Th}$. Thus, the $\mathrm{Th} / \mathrm{K}$ ratios are not anomalous $\left(5-7 \times 10^{-4}\right)$ and do not differ from the values in country-rock paragneisses (Fig. 4). In general, uniform concentrations of natural radioactive elements all over the ring may indicate an identical source of magma and short time interval of its effusion.

The huge thickness of the Teplice Rhyolite, found in boreholes drilled within the Teplice-Lahošt' horst (originally documented as the Přední Cínovec type), is characterized by homogeneous composition, suggesting a single lithological type (the deepest TP-39 borehole reached $1170 \mathrm{~m}$ ). In addition, several transitions between pyroclastic (ignimbrite) and crystallic (microgranite) textures were reported from the lower part of this borehole (Cuřín et al. 1989) together with frequent presence of large xenoliths (up to $1 \mathrm{~m}$ ) of the basement rocks. This is line with the possible proximity of a feeding conduit for the TR4 (Přední Cínovec type) penetrating the older units in the area of Teplice-Lahošt' horst (higher Th concentrations on eastern and western edges - see Fig. 5b).

A NW-SE trending fault (fault system) in the southern vicinity of the Altenberg town, named herewith Altenberg Fault, substantially attenuates and nearly squeezes the rhyolite body. The main manifestations of this fault are: (i) abrupt SE ending of the wide granite porphyry rim (Altenberg dyke) near the Czech/German border, (ii) sudden NE ending of the Lysá hora, Medvědí vrch and Přední Cínovec rhyolite types near the Czech/German border, (iii) NW-SE trending limit of the TR3a and TR3b ignimbrite units in the S vicinity of Altenberg, and (iv) remarkably linear NE limit of the Schellerhau granite intrusion. This interpreted fault matches the (quadrant) geological segmentation of the ATC by Mlčoch and Skácelová (2010).

\section{Conclusions}

- Substantial differences in radioactivity between the Older Intrusive Complex (Fláje Massif) and Younger Intrusive Complex (Schellerhau granite) were proven. In the airborne data, the Schellerhau Complex shows $1.5 \times$ times higher $\mathrm{K}$, double $\mathrm{U}$ and three times higher Th concentrations. 
- Distinct differences among previously defined lithological types of Teplice Rhyolite were documented in the Czech segment of the caldera. These characteristics were used for cross-border correlation as far as the Altenberg Fault. The northern segment of the caldera ( $\mathrm{N}$ of Altenberg) has dissimilar, less coherent and less continuous distribution of lithological types of rhyolites, suggesting that the northern segment of the caldera underwent a different evolution.

- Granite porphyry rimming the caldera has uniform radioactive properties around the entire exposed part of the caldera. It is well illustrated by the low $\mathrm{Th} / \mathrm{K}$ ratios. The uniform concentrations of radioactive elements may indicate the same source of magma.

- Our data support the existence of the NW-SE trending Altenberg Fault cross-cutting the ATVC in the southern vicinity of Altenberg. It splits the ATC to the northern (Saxon) and the southern (mostly Czech) segments. The southern, probably more subsided segment also exposes younger ignimbrite units eroded in the northern part.

- Using the concentrations of K and Th, the Czech Pramenáč type can be well correlated with the Saxon Lugstein type, even in the area north of Altenberg Fault. It also shows similar characteristics as scarcely exposed Vrchoslav type in the eastern part of the ATVC on the Czech side.

- Correlation of the Western margin type to the Langer Grundbach and Teichweg types is unfeasible due to wide variance of the measured data.

- Based on Th (19-48 ppm) and K (3.1-5.2 wt. \%) concentrations (ground gamma-ray spectrometry), the Vlčí kámen type (except for the type locality of the Vlčí kámen hill) corresponds well to the Medvědí vrch type, suggesting that all these represent a single unit underlying the Přední Cínovec type.

- The extent of the Přední Cínovec type is limited approximately along the state border.

- Our data support the idea of a partly symmetric caldera fill south of the Altenberg Fault, with the youngest ignimbrite (Přední Cínovec type) in the centre and older units on flanks. This hypothesis requires further testing by detailed petrological study.

- The rocks in the central part of the Teplice-Lahošt' horst most likely represent the conduit system for the TR4 (Přední Cínovec type) unit.

- In general, from the TR3a unit onwards, the K contents in the volcanic products and intrusives of the ATC were increasing with time, whereas the Th contents were decreasing. Recognition of the radioactive differences of the rhyolite lithotypes exposed in the southern segment of the caldera can be utilized in analogical studies of the more complicated northern (German) segment.
Acknowledgements. The research on petrophysical properties of the Altenberg-Teplice Volcanic Complex was carried out within the framework of the project "Reassessment of the groundwater resources" supported by the EU (Operational Program for Environment), the State Environment Fund of the Czech Republic and the Czech Ministry of Environment. We thank WISMUT GmbH for permitting access to several drill cores from the German part of the ATVC. The authors thank to Marta Chlupáčová and Jaromír Hanák for providing unpublished petrophysical data from the Mi-4 borehole. RCG would like to thank the German Academic Exchange Service (DAAD) for providing a scholarship for doctoral studies at the Institute for Geology and Palaeontology, TU Bergakademie Freiberg. The Czech-German cooperation in research on Late Paleozoic volcanic systems runs within the frame of the VENTS program (http://www.vents.ing.uni. wroc.pl/). We are grateful for constructive comments provided by Alistair T. McCay, Bernhard Schulz, and an anonymous reviewer as well as by handling editor Alexandra Guy.

Electronic supplementary material. Supplementary data for this paper (results of ground gamma-ray spectrometry, laboratory gamma-ray spectrometry from key outcrops and analysed drill-cores) as well as a map of uranium distribution based on airborne gamma-ray spectrometry are available online at the Journal website (http://dx.doi. org/10.3190/jgeosci.251).

\section{References}

Ackerman L, Haluzová E, Creaser RA, Pašava J, Veselovský F, Breiter K, Erban V, DrábeK M (2017) Temporal evolution of mineralization events in the Bohemian Massif inferred from Re-Os geochronology of molybdenite. Miner Depos 52: 651-662

ATtIA TE, WAHID AM (2016) Role of uranium in controlling radiogenic heat production based on gamma ray spectrometry and thermal remote sensing data, southwestern Sinai, Egypt. Environ Earth Sci 75: 296

BENEK R (1991) Aspekte einer Volumenbilanz paläovulkanischer Förderprodukte - Beispiel Teplice-Rhyolith (Ostdeutschland). Z Geol Wiss 19: 379-389

Breiter K, GNojeK I, Chlupáčová M (1998) Radioactivity patterns - constrains for the magmatic evolution of two-mica granites in the Central Moldanubian Pluton. Věst Čes geol úst 73: 301-311

Breiter K, Novák JK, Chlupáčová M (2001) Chemical evolution of volcanic rocks in the Altenberg-Teplice Caldera (Eastern Krušné Hory Mts., Czech Republic, Germany). Geolines 13: 17-22 
Breiter K, SvojtKa M, Ackerman L, Švecová K (2012) Trace element composition of quartz from the Variscan Altenberg-Teplice Caldera (Krušné hory/Erzgebirge Mts, Czech Republic/Germany): insights into the volcanoplutonic complex evolution. Chem Geol 326: 36-50

Breiter K, Gardenoví N, Vaculovič T, KanickÝ V (2013) Topaz as an important host for Ge in granites and greisens. Mineral Mag 77: 403-417

Breiter K, Ďurišová J, Hrstka T, Korbelová Z, HLOŽKová VAŇKová M, VAŠINOVÁ GaLIOVÁ M, KANICKÝ V, RAMBousek P, KNÉSL I, Dobeš P, Dosbaba M (2017) Assessment of magmatic vs. metasomatic processes in rare-metal granites: a case study of the Cínovec/Zinnwald Sn-W-Li deposit, Central Europe. Lithos 292-293: 198-217

BuRDA J (ed) (2016) Ground-Water Resources Evaluation, Annex 2/48 Hydrogeological Region 6133 - Teplice Rhyolite. Unpublished final report, Czech Geological Survey, Prague, pp 1-146 (in Czech)

Chiozzi P, Pasquale V, Verdoya M, Minato S (2001) Natural gamma-radiation in the Aeolian volcanic arc. Appl Radiat Isot 55: 737-744

Chiozzi P, Pasquale V, Verdoya M, Minato S (2003) Gamma-ray activity in the volcanic islands of the southern Tyrrhenian Sea. J Environ Radioact 67: 235-246

Cuřín M, KoŘalková J, Novák J, Wurmová M (1989) Teplice in Bohemia - Borehole TP-39, Summarizing Final Report - $1200 \mathrm{~m}$. Unpublished report, Geoindustria, Prague, pp 1-25 (in Czech)

EISENREICH M (ed) (1985) Evaluation of the Structural Borehole Mi-4. Unpublished report, Czech Geological Survey, Prague, pp 1-11 (in Czech)

EISENREICH M, Jeř́́BEK M (1978) Geological map of the Teplice Rhyolite at scale 1:10,000. Unpublished map, Czech Geological Survey, Prague

Förster H-J, Tischendorf G, Trumbull RB, GottesMANN B (1999) Late-collisional granites in the Variscan Erzgebirge, Germany. J Petrol 40: 1613-1645

GeHRING I (2004) The use of grain size dependent magnetic susceptibility and gamma-ray measurements for the detailed reconstruction of volcanostratigraphy; the case of La Fossa di Vulcano, S. Italy. J Volcanol Geotherm Res 138: 163-183

GNOJEK I, PřIChystal A (1985) A new zinc mineralization detected by airborne gamma-ray spectrometry in Northern Moravia (Czechoslovakia). Geoexploration 23: 491-502

GNoJek I, Zabadal S. SedLÁk J (2012) Airborne Geophysical Mapping of the $\mathrm{W}$ part of the České středohoři Mts. Unpublished report, Miligal Ltd., Brno and Ministry of the Environment of the Czech Republic, Prague, pp 1-44 (in Czech)

Hoffmann U, Breitkreuz C, Breiter K, Sergeev S, StaneK K, Tichomirowa M (2013) Carboniferous-
Permian volcanic evolution in Central Europe - U/Pb ages of volcanic rocks in Saxony (Germany) and northern Bohemia (Czech Republic). Int J Earth Sci 102: 73-99

Hoth K, Wasternack J, Berger H-J, Breiter K, MlČOCh B, SchováneK P (1995) Geologische Karte Erzgebirge/ Vogtland, 1 : 100 000. Sächsisches Landesamt für Umwelt und Geologie, Bereich Boden und Geologie, Freiberg

IAEA TecDoc-1363 (2003) Guidelines for radioelement mapping using gamma-ray spectrometry data. International Atomic Energy Agency (IAEA), Vienna. Accessed on March 6, 2018, at https://www-pub.iaea.org/mtcd/ publications/pdf/te_1363_web.pdf

JiráneK J, KŘíbek B, Mlčoch B, Procházka J, SchováneK P, Schovánková D, Schulmann K, Šebesta J, ŠImŮNeK Z, ŠTEMPRoK M (1987) Complex Geological Evaluation of the Teplice Rhyolite. Unpublished report, Czech Geological Survey, Prague, pp 1-114 (in Czech)

Johan Z, Strnad L, Johan V (2012) Evolution of the Cínovec (Zinnwald) Granite Cupola, Czech Republic: composition of feldspars and micas, a clue to the origin of W, Sn mineralization. Canad Mineral 50: 1131-1148

Kanzari A, Gérard M, Boekhout F, Galoisy L, Calas G, Descostes M (2017) Impact of incipient weathering on uranium migration in granitic waste rock piles from former U mines (Limousin, France). J Geochem Explor 183: 114-126

KopaČKová V, MišUReC J, JeLÉneK J (2013) Report on Remote Sensing. In: KADLECOVÁ R (ed) Stage Report on the Reassessment of Ground-Water Resources. Unpublished report, Czech Geol Survey, Prague, pp 1-41 (in Czech)

Leichmann J, Gnojek I, Novák M, Sedlák J, Houzar S (2016) Durbachites from the Eastern Moldanubicum (Bohemian Massif): erosional relics of large, flat tabular intrusions of ultrapotassic melts - geophysical and petrological record. Int J Earth Sci 106: 59-77

LoBIN M (1986) Aufbau und Entwicklung des Permosiles im östlichen und mittleren Erzgebirge. Unpublished $\mathrm{PhD}$ thesis, TU Bergakademie, Freiberg, pp 1-63

McCAY AT, Younger PL (2017) Ranking the geothermal potential of radiothermal granites in Scotland: are any others as hot as the Cairngorms? Scott J Geol 53: 1-11

McCay AT, Harley TL, Younger PL, Sanderson DC, Cresswell AJ (2014) Gamma-ray spectrometry in geothermal exploration: state of the art techniques. Energies 7: 4757-4780

MLČOCH B (ed) (1989) Geological map of the ČSSR $1: 25$ 000, sheet 02-314 Litvínov. Czech Geological Survey, Prague

MLČOCH B, SKÁCelová Z (2010) Geometry of the Altenberg-Teplice Caldera revealed by the borehole and seismic data in its Czech part. J Geosci 55: 217-229

Moesta G (1929) Brüche und Porphyreffusionen im östlichen Erzgebirge. Z Dtsch geol Gesell 80 (Abh): 343-408 
Müller A, Seltmann R (2002) Plagioclase-mantled K-feldspar in the Carboniferous porphyric microgranite of Altenberg-Frauenstein, Eastern Erzgebirge/Krušné Hory. Bull Geol Soc Finland 74: 53-79

Müller A, Breiter K, Seltmann R, Pécskay Z (2005) Quartz and feldspar zoning in the eastern Erzgebirge Volcano-Plutonic Complex (Germany, Czech Republic): evidence of multiple magma mixing. Lithos 80: 201-227

PÄlChEN W, OssenKopf P (1967) Über das relative Alter des Schellerhauer Granitmassivs und seiner Varietäten. Ber Dtsch Ges Geol Wiss B 12: 359-371

Pälchen W, Walter H (eds) (2011) Geologie von Sachsen I - Geologischer Bau und Entwicklungsgeschichte. Schweizerbart Science Publishers, Stuttgart, pp 1-537

Paoletti V, Gruber S, Varley N, D'Antonio M, Supper R, Motschка K (2016) Insights into the structure and surface geology of Isla Socorro, Mexico, from airborne magnetic and gamma-ray surveys. Surv Geophys 37: 601-623

Rihs S, Gontier A, Pelt E, Fries D, Turpault MP, ChaBAUX F (2016). Behavior of $U$, Th and Ra isotopes in soils during a land cover change. Chem Geol 441: 106-123

Romer RL, Thomas R, Stein HJ, Rhede D (2007) Dating multiply overprinted Sn-mineralized granites - examples from the Erzgebirge, Germany. Miner Depos 42: 337-359

Romer RL, Förster HJ, ŠTEMProK M (2010) Age constraints for the late-Variscan magmatism in the Altenberg-Teplice Caldera (Eastern Erzgebirge/Krušné hory). Neu Jb Mineral, Abh 187: 289-305

RöTZler K, Plessen B (2010) The Erzgebirge: a pile of ultrahigh- to low-pressure nappes of Early Palaeozoic rocks and their Cadomian basement. In: LinNEMANN U, Romer RL (eds) Pre-Mesozoic Geology of SaxoThuringia. Schweizerbart Science Publishers, Stuttgart, pp 253-270

RuHL A (1985) Aerogeophysik Elbezone. Unpublished report, Archiv Landesamt für Umwelt, Landwirtschaft und Geologie, Freiberg, pp 1-20

RuHL A (1987) Aerogeophysik Lausitzer Scholle. Unpublished report, Archiv Landesamt für Umwelt, Landwirtschaft und Geologie, Freiberg, pp 1-34

RuHL A (1990) Aerogeophysik Mittelerzgebirge. Unpublished report, Archiv Landesamt für Umwelt, Landwirtschaft und Geologie, Freiberg, pp 1-79

Sedlák J, Gnojek I, Verner K, FraněK J, Zabadal S, MotschKa K, SLOvík J (2011) Geophysical and structural pattern of the Knížecí Stolec Pluton and its host rocks in the south-western part of the Moldanubian Zone, Bohemian Massif. J Geosci 56: 143-162

Sedlák J, Gnojek I, Skáceloví Z, Mlčoch B (2014) The Teplice Rhyolite - airborne geophysical survey - 2013. In: Magna T, RAPPRich V, RAdoŇ M (eds) Meeting of the Expert Volcanology Group of the Czech Geological Society, 6.-7. 10. 2014, Dlouhá Louka. Czech Geological Survey, Prague, pp 25-26 (in Czech)
Seifert T, Atanasova P, Gutzmer J, Pfänder J (2011) Mineralogy, geochemistry and age of greisen mineralization in the Li-Rb-Cs-Sn-W deposit Zinnwald, Erzgebirge, Germany. Mineral Mag 75 (Suppl): 1833

SeltMAnN R, ŠTeMPRoK M (1995) Metallogenic overview of the Krušné Hory Mts. (Erzgebirge) region. In: BreITER K, Seltmann R (eds) Ore Mineralizations of the Krušné Hory Mts. (Erzgebirge). Excursion Guide, $3^{\text {rd }}$ Biennial SGA Meeting Prague. Czech Geological Survey, Prague, pp 1-18

Skácelová Z, Rapprich V, Mlčoch B (2009) Effect of small potassium-rich dykes on regional gamma-spectrometry image of a potassium-poor volcanic complex: a case from the Doupovské hory Volcanic Complex, NW Czech Republic. J Volcanol Geotherm Res 187: 26-32

ŠTEMPROK M (2016) Drill core CS-1 penetrating the Cínovec/ Zinnwald granite cupola (Czech Republic). A review of A-type granite magmatic emplacement and important hydrothermal mineralization. J Geosci 61: 395-423

ŠTEMPRoK M, Blecha V (2015) Variscan Sn-W-Mo metallogeny in the gravity picture of the Krušné hory/ Erzgebirge granite Batholith (Central Europe). Ore Geol Rev 69: 285-300

ŠTEMProK M, Holub FV, Novák JK (2003) Multiple magmatic pulses of the Eastern Volcano-Plutonic Complex, Krušné hory/Erzgebirge Batholith, and their phosphorus contents. Bull Geosci 78: 277-296

Tschesnokow WK, Olenin WW, Kutschke D (1973) Geological map of the Teplice tectono-volcanic structure. Unpublished map, Wismut SDAG, Freiberg

WALTHER D (2013) Lithostratigraphie der karbonen Schönfeld Formation anhand der Bohrung 2055/85 (Altenberg-Teplice Vulkanit-Komplex). Unpublished Bachelor Thesis, TU-Bergakademie, Freiberg, pp 1-45

WaLther D, BreitKreuz C, RapPrich V, Kochergina YV, Chlupéčová M, Lapp M, Magna T (2016) The Late Carboniferous Schönfeld-Altenberg depression in the German-Czech border region: volcanosedimentary evolution and petrological constraints. J Geosci 61: 371-393

Weinermann JD, Ferreira FJF, Cury LF, da Silveira CT (2016) Gamma-ray spectrometry of granitic suites of the Paranaguá Terrane, Southern Brazil. J Appl Geophys 132: $38-52$

Wetzel H-U (1984) Spätvariszische Bruchtektonik und subsequente Gangmagmatite als Ausdruck der Krustenentwicklung im Osterzgebirge (Altenberger Scholle). Unpublished $\mathrm{PhD}$ thesis, Zentralinstitut für die Physik der Erde, Potsdam, pp 1-230

Winter C, BreitKreuz C, LAPP M (2008) Textural analysis of a Late Palaeozoic coherent to pyroclastic rhyolitic dyke system near Burkersdorf (Erzgebirge, Saxony, Germany). In: Thomson K, Petford N (eds) Structure and Emplacement of High-Level Magmatic Systems. Geological Society of London Special Publications 302: 197-219 
ZabadAl S, Gnojek I, Sedlák J (2014) Airborne Gammaray Spectrometry and Magnetometry, Area No. 6, Teplice Rhyolite Body and the Děčín Part of the Czech Cretaceous Basin. Unpublished report, Miligal Ltd., Brno and Czech Geological Survey, Prague, pp 1-53 (in Czech)
Zachariáš J, Adamovič J, KoneČnÝ P (2008) The uraninite-pyrite association, a sensitive indicator of changes in paleofluid composition: an example from the Ohře (Eger) Graben, Bohemian Massif, Czech Republic. Canad Mineral 46: 1159-1172 